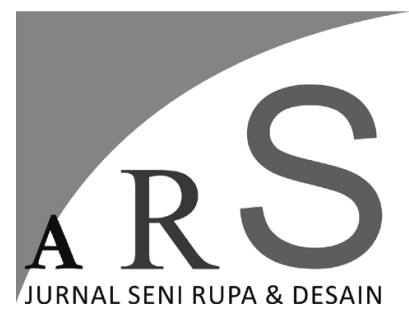

Volume 23 Nomor 2 Mei - Agustus 2020

\title{
INOVASI ORNAMEN MASJID AGUNG DEMAK UNTUK MOTIF BATIK KONTEMPORER KHAS DEMAK
}

\author{
Abi Senoprabowo, Deddy Award Widya Laksana dan \\ Teddy Prakosa Putra \\ Program Studi Desain Komunikasi Visual, Fakultas Ilmu Komputer \\ Universitas Dian Nuswantoro \\ Jalan Imam Bonjol no 207 Kota Semarang, Tlp. 085640739977, \\ E-mail: abiseno.p@gmail.com
}

\begin{abstract}
ABSTRAK
Dahulu ornamen Masjid Agung Demak digunakan sebagai motif batik yang menarik dan unik. Tetapi sekarang ini sudah ditinggalkan oleh pembatik karena dianggap sudah tidak menarik. Batik mengalami perkembangan fungsi, yakni tidak hanya sebagai karya murni yang didesain untuk menampilkan nilai estetik, tetapi juga memiliki fungsi sebagai bahan untuk busana dan kelengkapan fungsional lainnya. Secara khusus, penelitian ini diarahkan pada eksplorasi desain ornamen dalam pengembangan desain motif batik kontemporer berbasis konservasi budaya pada seni perbatikan Kabupaten Demak. Metode perancangan menggunakan teori proses penciptaan seni kriya dari Gustami yaitu Proses eksplorasi, Proses perancangan karya, dan Proses perwujudan. Proses eksplorasi dilakukan untuk pencarian ide dengan pengumpulan dan pencarian data menggenai ornamen-ornamen Masjid Agung Demak dengan cara studi literatur dan observasi langsung ke Masjid Agung Demak. Proses perancangan karya diawali dengan brainstorming dan dilanjukan proses visualisasi. Proses perwujudan melakukan finalisasi desain dan pengaplikasian karya. Motif batik yang dihasilkan telah mempertimbangkan target audiens yang dituju yaitu anak muda usia 15-30 tahun dan mempertimbangkan tren yang sedang populer sekarang ini. Teknik penciptaan batik yang disarankan adalah teknik cap, teknik sablon, dan teknik cetak printing. Motif batik yang dihasilkan juga sudah diterapkan di media tas totebag dan sarung bantal.
\end{abstract}

Kata kunci: Ornamen, Masjid Agung Demak, Batik

\begin{abstract}
The Innovation of Demak Great Mosque Ornaments for Demak Contemporary Batik Motifs. Previously, the ornament of the Great Mosque of Demak was used as an interesting and unique batik motif. But now it has been canceled by batik craftsman because it is considered not attractive. Batik has developed a function, which is not only a pure work designed to display aesthetic value, but also has a function as material for clothing and other functional equipment. Specifically, this research is aimed at exploring ornamental designs in the development of batik motifs. The design method uses the theory of the process of creating art of crafts from Gustami, namely the exploration process, the design process of the work, and the embodiment process. The exploration process is carried out to find ideas by collecting and searching data on the ornaments of the Great Mosque of Demak using literature study and direct observation of the Great Mosque of Demak. The design process of the work begins with brainstorming and continues the visualization process. The embodiment process finalizes the design and application of the work. The batik motifs produced must be considered by the intended target audience of young people aged 15-30 years and consider the trends that are currently popular. Recommended batik creation techniques are stamp technique, screen printing technique, and printing machine technique. The batik motifs produced have also been applied in the media of tote bags and pillowcases.
\end{abstract}

Keywords: Ornaments, The Great Mosque of Demak, Batik 


\section{Pendahuluan}

Kegiatan berkesenian adalah hasil dari kebudayaan manusia yang seharusnya dapat didokumentasikan, dipublikasikan, dilestarikan, dan dikembangkan yang dapat digunakan sebagai upaya menuju kemajuan peradaban dan mempertinggi derajat kemanusian dan kebudayaan (Wulan \& Affandi, 2016). Dalam pemenuhan kebutuhan estetik manusia, kesenian menjadi bagian yang tidak terpisahkan. Berbagai bentuk kesenian sebagai manifestasi dari pemenuhan kebutuhan estetik manusia tersebut. Ditinjau dari perspektif kebudayaan, seni hadir dalam hubungan yang kontekstual dengan ruang dan waktu tempat karya tersebut dilahirkan. Di Indonesia batik adalah seni yang sudah mentradisi dan merakyat. Kata batik berasal dari bahasa Jawa yaitu "ambatik" yang berarti "menulis" dan "titik". Sedangkan pengertian batik secara umum yaitu proses penggambaran pada kain mori dengan menggunakan alat bantu canting, dimana untuk menghasilkan motif batiknya menggunakan cairan lilin atau biasa disebut malam(Pebrianasari, Mulyanto, \& Dolphina, 2015).

Munculnya keragaman corak ragam hias batik yang bervariatif pada tiap daerah merupakan bagian dari ekspresi maupun kreativitas seni yang memperkaya khasanah budaya Indonesia. Keunikan dari gaya dan bentuk ragam hias batik pada umumnya dipengaruhi kaitannya dengan beberapa faktor penting, di antaranya letakgeografis dan budaya masarakat yang ada di daerah yang bersangkutan (Karmila, 2010). Kekhasan ragam hias batik merupakan sebuah substansi bentuk dan makna yang menampilkan nuansa-nuansa berbeda sehingga menunjukkan identitas masingmasing wilayah penghasil batik. Ekspresi seni yang muncul dalam wujud karya batik merupakan ekspresi seni dan refleksi budaya dan adat istiadat sehingga batik di Indonesia terus mangalami perubahan dan perkembangan (Gustami, 2008). Keberadaan batik, secara epistemologis dapat dikatakan merupakan bagian dari upaya pemenuhan kebutuhan hidup manusia yang senantiasa mengalami perkembangan (Soedarso, 2006). Lewat keterampilan dan kreativitas dengan penggunaan teknologi dalam membatik, maka muncul karya batik sebagai bentuk ekspresi estetik dari pembuatnya (Kartika, 2005).
Ekplorasi gagasan yang mengangkat dan mewujudkan ide perajin dalam mengkreasikan motif batiknya yang berbasis pada budaya, khususnya pengembangan desain motif dengan memodifikasi ornamen interior pada masjid agung Demak. Pengembangan desain motif dengan memodifikasi ornamen interior pada masjid agung Demak unik dapat dipandang sebagai sebuah perbendaharaan dalam pengembangan motif batik kontemporer dan khas pada perbatikan di Kabupaten Demak. Batik di Kabupaten Demak dewasa ini telah lepas dari ikon kabupaten Demak itu sendiri. Batikbatik yang muncul terlalu kontemporer dengan mengambil ikon-ikon kabupaten Demak yang sedang berkembang saat ini seperti belimbing, jambu air, tumpeng, pantai, dan lain sebagainya. Padahal di satu sisi, kabupaten Demak memiliki Masjid Agung Demak yang telah dikenal oleh masyarakat luas. Masjid Agung Demak memiliki ornamen yang tersebar di berbagai tempat seperti di pintu masuk, mimbar, tempat imam, pilar, dinding, dan lain sebagainya. Ornamen yang ada di Masjid Agung Demak sangat menarik dan banyak unik. Pada zaman dahulu, ornamen di Masjid Agung Demak digunakan sebagai motif batik. Tetapi sekarang ini sudah ditinggalkan oleh pembatik karena dianggap sudah tidak menarik.

Selain itu pula, batik mengalami perkembangan fungsi, yakni tidak semata sebagai karya murni yang didesain untuk menampilkan nilai estetik, tetapi juga dapat digunakan dengan fungsi sebagai bahan untuk busana dan kelengkapan fungsional lainnya sebagai fungsi terapan. Penerapannya juga sudah berkembang dalam berbagai media seperti tas, topi, sarung bantal, mural, cat mobil, dan lain sebagainya. Dengan pertimbangan itu pula penelitian ini secara khusus melakukan penciptaan berkaitan dengan fenomena tersebut, yakni mencari jawaban atas bagaimana kemunculan gagasan perajin dalam mengekspresikan tema-tema ornamen interior pada masjid agung Demak ke dalam pengembangan desain motif batiknya. Secara khusus, penelitian ini diarahkan pada eksplorasi desain ornamen dalam pengembangan desain motif batik kontemporer berbasis konservasi budaya pada seni perbatikan Kabupaten Demak. Penelitian ini dipandang 
perlu dilakukan dengan mempertimbangkan manfaat yang akan diperoleh, yakni temuan empirik dan pengembangan teoretik desain sebagai ekspresi dan identitas budaya khususnya tentang perbatikan Kabupaten Demak dalam memberikan penguatan identitas budaya lokal yang berbasis konservasi budaya melalui eksplorasi dan pengembangan desain motif batik kontemporer. Selain itu, motif batik yang digunakan dapat dijadikan sebagai motif rujukan pembatik di Kabupaten Demak.

\section{Ornamen}

Ornamen atau Ragam Hias adalah Komponen produk seni yang ditambahkan atau sengaja dibuat untuk tujuan sebagai hiasan,yang bersifat estetis (Sunaryo, 2009). Ornamen sudah berkembang sejak jaman manusia purba yang dapat dilihat dalam berbagai bahasa gambir pictogram. Bahasa gambar pictogram adalah alat kumunikasi lewat motif-motif gambar yang masih perlu ditafsirkan kembali makna pesan yang akan disampaikan (Saragi, 2018). Dari gambar pictogram tersebut terciptalah motif-motif yang digunakan dalam berbagai hal. Ornamen-ornamen tersebut sangat berkembang hidup di kawasan Nusantara. Salah satu sifat dari kesenian Nusantara adalah jarang dijumpai bidang kosong dalam kesenian Nusantara, semuanya diisi dengan ornamen yang kadang tampak berlebihan. Dalam mengisi bidang kosong tersebut, kesenian nusantara pada umumnya melalui pengubahan bentuk tergayakan (stilasi) \& bernilai hias.

Setiap ornamen di kebudayaan Nusantara dapat dipastikan selalu memiliki makna dan fungsi tertentu (Mayasari, Tulistyantoro, \& Rizqy, 2014). Fungsi utama jika dilihat dari pengertian ornamen adalah untuk memperindah objek, benda, atau barang. Objek yang akan ditambahkan ornamen mungkin sudah indah, tetapi diharapkan menjadi semakin indah setelah ditambahkan ornamen (Sudana, 2019). Penambahan ornamen pada sebuah produk pada umumnya membuat penampilan lebih menarik dan oleh karena itu menjadi lebih bernilai. Hal tersebut dapat meningkatkan penghargaan terhadap produk tersebut. Selain itu fungsi fungsi ornamen dapat disederhakan menjadi beberapa fungsi, yaitu fungsi estetik, fungsi utilitarian, fungsi individu, dan fungsi sosial. Fungsi yang tertinggi adalah fungsi spiritual yang dapat dilihat dari fungsi pokok ornamen Nusantara sebagai sarana membangkitkan kepekaan tanggapan emosional, yang dapat membina keseimbangan hidup perorangan maupun kolektif dengan alam dan pencipta (Ashari, 2013). Untuk perkembangan ornamen sekarang, fungsi simbolik adalah fungsi yang yang banyak diperlihatkan seperti untuk menunjukan status sosial dan kepangkatan tertentu.

\section{Motif dan pola}

Motif adalah tema atau ide dasar sebuah ornamen (Sunaryo, 2009). Secara pengertian yang lebih luas, motif adalah suatu kerangka bergambar yang menjadi dasar untuk mewujudkan ornamen secara keseluruhan (Arisandi, Suciati, \& Wijaya, 2011). Motif dapat dikenali sebab perwujudan motif pada umumnya merupakan gubahan atas bentuk di alam yang kasat mata. Tetapi ada pula yang merupakan hasil khayalan atau imajinasi yang biasa disebut motif abstrak. Namun secara garis besar, motif terbagi menjadi dua kelompok jenis yaitu motif geometri dan motif non-geometri. Dari motif non geometris ini, baru akan muncul jenis-jenis motif yang banyak seperti Motif manusia, Motif binatang, Motif tumbuhan, Motif benda alam, Motif benda teknologis, dan motif kaligrafis.

Sedang dalam ornamen, bentuk pengulangan motif secara struktural disebut sebagai pola. Pengertian pola hias secara lebih luas adalah unsur dasar ornamen yang didapat dari hasil susunan dari motif hias tertentu dalam bentuk dan komposisi yang tertentu dipakai sebagai pedoman untuk menyusun suatu hiasan (Saragi, 2018). Pengulangan motif untuk membuat pola dapat dilakukan secara horisontal, vertikal, maupun miring. Sebuah pola yang merupakan susunan motif, dapat diulang-ulang sehingga dapat menjadi motif yang baru. Tapi dalam berbagai literatur, motif batik dapat juga disebut corak batik atau pola batik.

\section{Metode dan Tujuan Penelitian}

Metode perancangan yang digunakan dalam pembuatan karya desain motif batik Demak kontemporer adalah dengan menggunakan 
teori proses penciptaan seni kriya dari Gustami (2007), yaitu dengan tiga pilar penciptaan karya kriya yang dijabarkan sebagai berikut,

a. Proses eksplorasi adalah tahap pencarian ide yang dilanjutkan dengan pengumpulan dan pencarian data mengenai sumber informasi yang akan digunakan dalam proses penciptaan karya. Dalam proses ini, dilakukan pengumpulan data mengenai ornamen-ornamen yang ada di Masjid Agung Demak. Informasi dan data yang dibutuhkan didapatkan dengan cara studi literatur dan observasi langsung ke Masjid Agung Demak. Hasil dari studi literatur akan di analisis yang hasilnya menjadi acuan untuk melakukan perancangan.

b. Proses perancangan karya adalah proses yang dilaksanakan setelah mendapatkan data yang dituangkan dalam bentuk ide. Ide yang didapat dari proses brainstorming atau curah pendapat. Brainstorming atau curah pendapat adalah cara yang dilakukan oleh perorangan ataupun berkelompok untuk memunculkan ide-ide bebas dan liar yang nantinya dipilih yang terbaik (Marianto, 2006). Hasil dari proses brainstorming akan dilanjukan pada proses memvisualisasikan hasil dari penjelajahan tersebut kedalam berbagai alternatif desain (sketsa).

c. Proses perwujudan dilakukan dengan cara menentukan rancangan atau sketsa terpilih yang dijadikan acuan dalam pembuatan rancangan final. Rancangan Final ini akan dijadikan acuan dalam proses perwujudan karya.

\section{Hasil dan Pembahasan \\ Proses eksplorasi}

Masjid Agung Demak merupakan Masjid bersejarah dan salah satu masjid tertua yang ada di Indonesia. Masjid Agung Demak berada di tengah kota atau alun-alun kota Demak, Jawa Tengah. Masjid ini berdiri pada awal abad ke 15 pada masa kepemimpinan Raden Patah, sultan pertama Kesultanan Demak. Masjid ini didirikan atas sumbangsih dari Wali Sanga yang ikut serta pada pembangunan masjid ini.

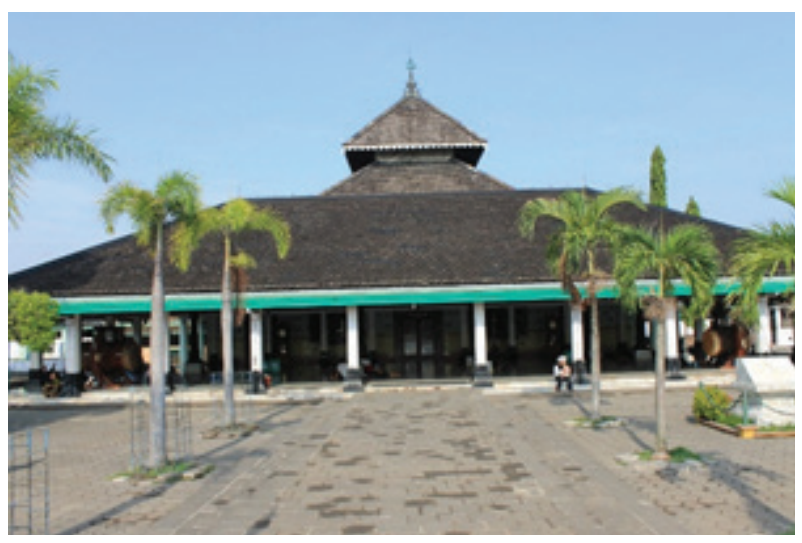

Gambar 1. Foto Masjid Agung Demak tampak dari depan (Sumber: Dokumentasi Abi Seno dkk., 2020)

Salah satu hal yang menarik dari bangunan Masjid Agung Demak adalah keberadaan beragam ornamen. Ornamen merupakan seni hias yang juga ada dalam agama Islam. Seperti dalam penelitian Supatmo (2016), didalam bangunan Masjid Agung Demak terdapat setidaknya 5 ornamen utama, yaitu (1) ornamen ukir Saka Majapahit; (2) ornamen porselen pada dinding; (3) ornamen sengkalan memet bermotif bulus; (4) ornamen Pintu Bledheg; dan (5) ornamen Surya Majapahit.

Ornamen Saka Majapahit berupa ornamen ukir paduan motif tumbuhan menjalar, tumpal, dan kelopak daun Teratai di bagian bawah. Pada ornamen porselen pada dinding bangunan, motif yang muncul adalah dominan motif flora berupa tumbuhan, bunga, ranting-ranting dan dedaunan. Terdapat juga beberapa motif flora, seperti motif burung dan motif sayap burung. Pada ornamen Sengkalan Memet yang ada di ruangan tempat imam memimpin shalat (Mibrab) berupa ornamen Bulus (kura-kura air sungai). Pada bagian tengah motif bulus tersebut terdapat ornamen keramik berpola kupu-kupu. Pada ornamen Pintu Bledheg terdapat motif tumbuhtumbuhan, suluran, jambangan, mahkota, tumpal, camara, dan kepala naga. Ornamen yang terakhir adalah ornamen Surya Majapahit. Ornamen Surya Majapahit berbentuk bintang delapan dengan lingkaran bulat di tengahnya, penggambaran matahari (surya) dengan sinar cahayanya. 


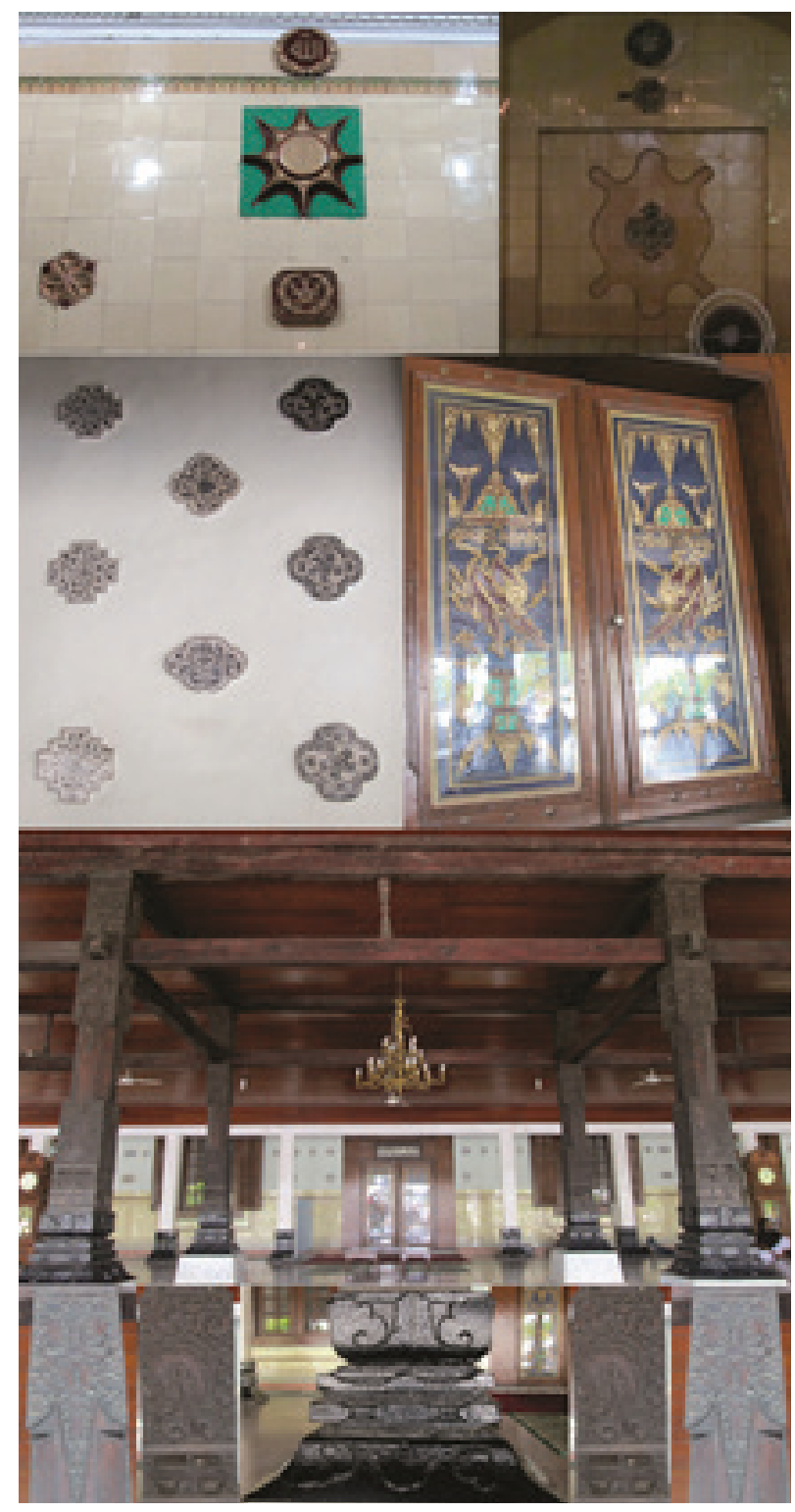

Gambar 2. Berbagai ornamen di bangunan Masjid Agung Demak

(Sumber: Dokumentasi Abi Seno dkk., 2019)

Dari berbagai ornamen yang terdapat di bangunan Masjid Agung Demak, ornamen yang menarik dan akan dijadikan motif untuk batik khas Demak adalah Ornamen Lawang Bledheg. Ornamen Lawang Bledheg dipilih karena sangat unik dan sangat fenomenal karena satu-satunya ornamen yang berbentuk seperti itu, serta sangat menonjol dibanding ornamen-ornamen pada obyek lain.

Pintu Bledheg merupakan sebuah pintu utama Masjid Agung Demak untuk menuju dalam ruang Sholat. Pintu Bledheg merupakan daun pintu yang terbuat dari bahan kayu Jati yang dipenuhi dengan ukiran. Pintu Bledheg dipercaya masyarakat dibuat oleh Ki Ageng Selo. Ukiran yang ada pada Pintu Bledheg seperti motif tumbuhtumbuhan, suluran, jambangan, mahkota, tumpal, camara, dan kepala Naga dengan mulut terbuka menampakkan gigi-giginya. Pintu tersebut dinamakan Pintu Bledheg karena dihubungkan dengan cerita yang berkembang di Masyarakat bahwa Ki Ageng Selo menangkap bledheg (petir) yang wujudnya menyerupai seekor Naga.

Ornamen Pintu Bledheg terdiri dari beberapa bagian. Pada bagian atas terdapat motif tumpal dan sulur atau lung. Lalu dibawahnya terdapat motif mahkota dan camara. Motif kepala naga tepat berada di tengah pintu tersebut. Pada bagain bawah teradapat motif jambangan. Dalam ornamen tersebut terdapat juga lambang Surya Majapahit yang dijadikan mata naga. Seperti pada penelitian Supatmo (2018), Ornamen pada Pintu Bledheg memiliki arti yang mendalam. Motif tumpal menjadi simbol hubungan antara manusia dengan Tuhan. Pada motif mahkota merupakan simbol Al-Wahid yang pada agama Islam berarti tentang Ketuhanan yang maha esa. Untuk motif kepala naga, merupakan simbol kekuatan dalam berdakwah menyebarkan agama Islam. Motif jambangan adalah simbol agama Islam yang merupakan simbol ajaran Islam agar menjadi rahmat bagi semesta alam. Serta motif bunga dan tumbuhan merupakan simbol kesuburan dan kesejahteraan. Keragaman latar dari motif-motif tersebut menjadi manifestasi sikap fleksibel dan toleransi terhadap ajaran para Wali Sanga. Mitos Ki Ageng Selo menangkap bledheg bisa dipahami merupakan kiasan yang secara simbolis divisualisasikan ke dalam ornamen sebagai media dakwah.

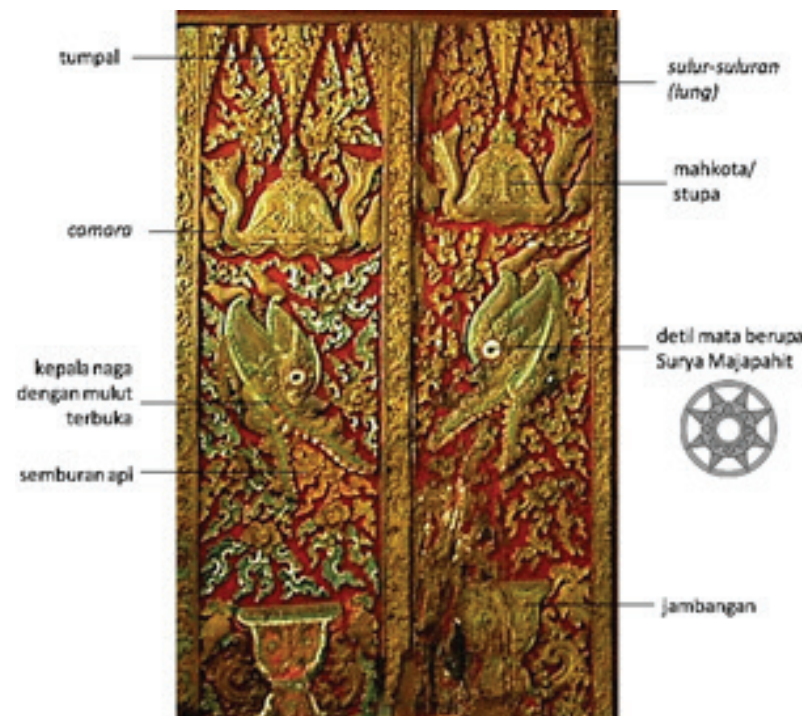

Gambar 3. Ornamen Lawang Bledheg yang ada di pintu masuk Masjid Agung Demak (Sumber: Supatmo, 2016) 


\section{Proses perancangan}

Setelah melalui proses eksplorasi, motif Lawang Bledheg adalah ornamen yang akan digunakan untuk mengembangkan motif khas Demak karena keunikannya. Unsur yang ada pada ornamen Lawang Bledheg tidak semuanya digunakan. Dipilih beberapa yang menarik dan sesuai. Target audiens dari batik kontemporer ini adalah anak muda dengan rentang usia 15-30 tahun yang memiliki selera modern. Oleh karena itu, motif yang dipilih adalah motif Kepala Naga, Tumpal, dan Surya Majapahit. Ketiga ornamen ini akan dipadukan menjadi sebuah motif yang baru.

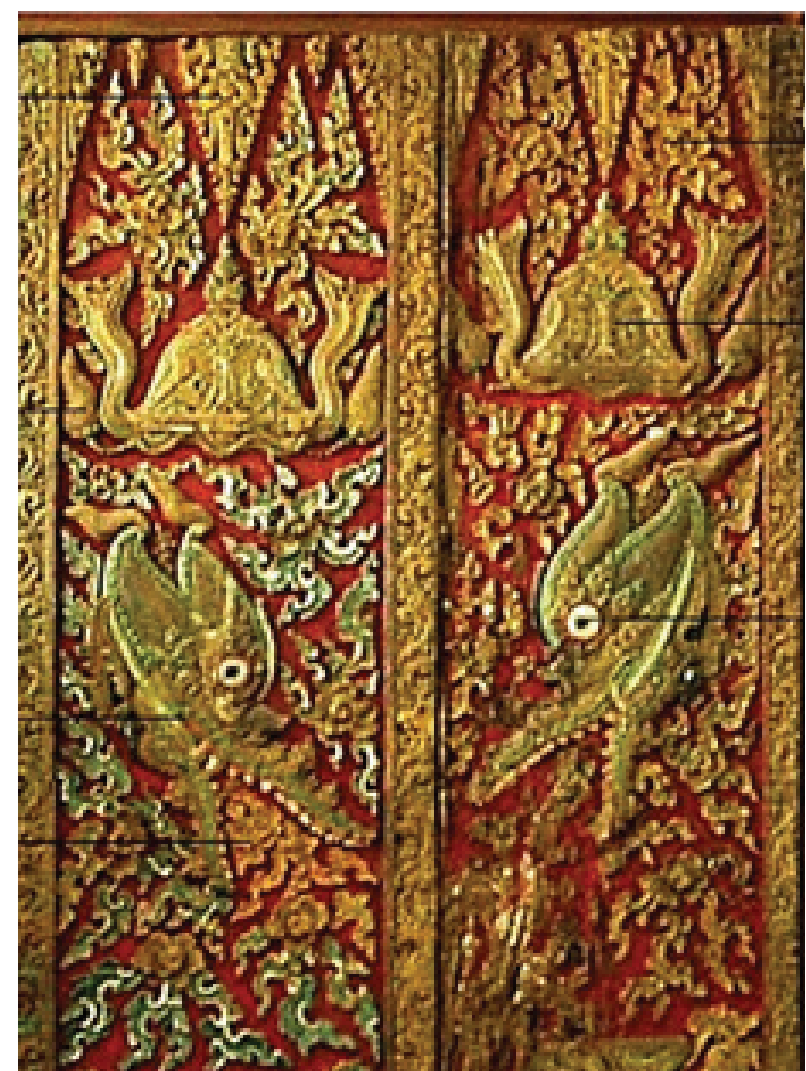

Gambar 4. Bentuk Naga dan tumpal pada Ornamen Lawang Bledheg Masjid Agung Demak (Sumber: Reproduksi Abi Seno dkk., 2020)

Lambang Surya Majapahit didapat pada mata Kepala Naga. Untuk memperjelas hal tersebut, maka referensinya diambil dari motif Surya Majapahit yang ada di atas ruangan tempat imam Sholat. Lambang yang ada terlihat lebih mudah untuk dikembangkan ke dalam desain motif batik.

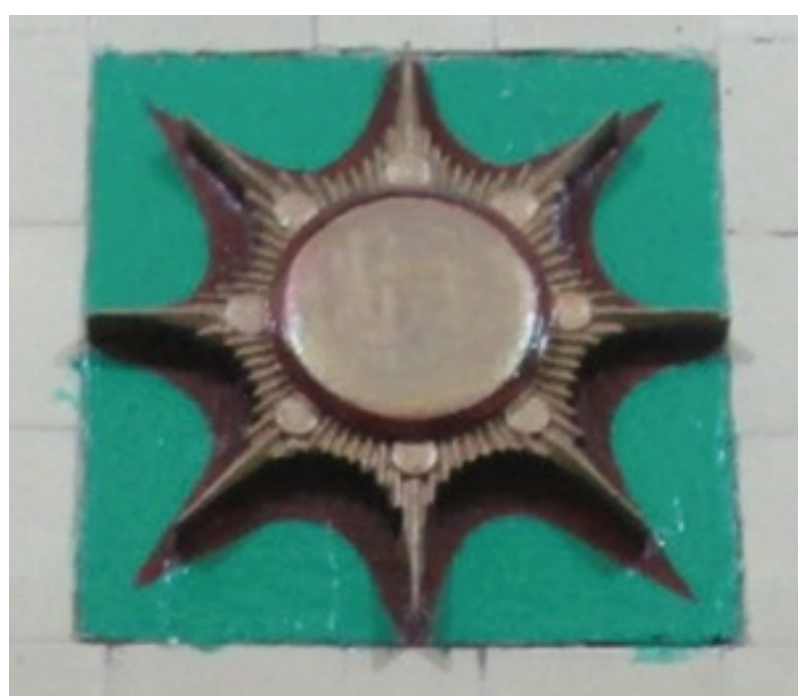

Gambar 5. Surya Majapahit yang ada di atas Mimbar Masjid

(Sumber: Dokumentasi Abi Seni dkk., 2019)

Dari referensi gambar yang didapat, proses selanjutnya dilakukan proses brainstorming melalui pembuatan sketsa desain. Pengembangan dua buah rancangan dilakukan dengan mengacu pada referensi yang ada. Bentuk motif kepala Naga menjadi bentuk utama. Sedang ornamen Tumpal dan Surya Majapahit digunakan sebagai ornamen isian.

Pada sketsa alternatif desain yang pertama, digunakan penggayaan dengan gaya semi realis dengan garis tegas yang menggambarkan sosok kepala Naga secara jelas. Hal ini dimaksudkan untuk menimbulkan pandangan visual yang keren bagi anak muda yang menikmati karyanya. Penggayaan seperti ini sedang digemari anak muda apabila ditambahkan dengan finishing gaya vector dengan pewarnaan flat colour and limited palette.

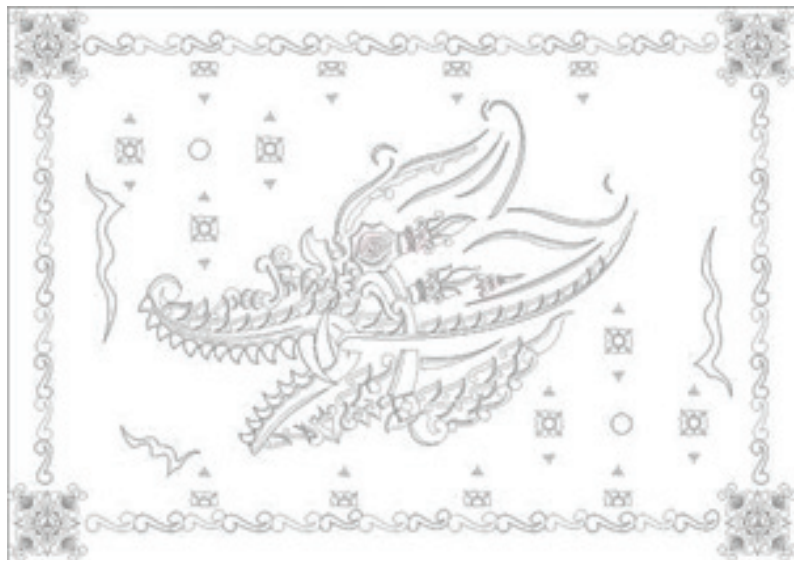

Gambar 6. Alternatif I sketsa pengembangan ide motif Bentuk Naga pada Ornamen Lawang Bledheg (Sumber: Dokumentasi Abi Seno dkk., 2020) 
Pada sketsa alternatif desain yang kedua, digunakan penggayaan dengan gaya abstract illustration. Penampakan yang terlihat pada bentuk raut dengan bentuk blok geometris sehingga membentuk ilustrasi kepala naga secara abstrak. Tren gaya seperti ini berkembang karena anak muda sekarang menyukai ilustrasi sederhana, keunikan, dan grafis sederhana. Penggayaan seperti ini diikuti dengan penggunaan warna pop dengan menggunakan warna-warna terang dan kontras.

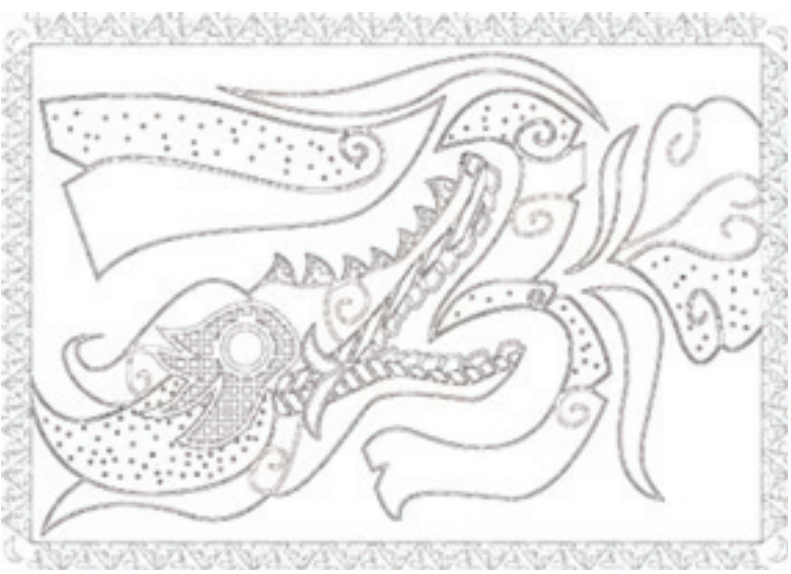

Gambar 7. Alternatif II sketsa pengembangan ide motif Bentuk Naga pada Ornamen Lawang Bledheg (Sumber: Dokumentasi Abi Seno dkk., 2020)

\section{Proses perwujudan}

Dalam proses perwujudan batik khas Demak berdasarkan ornamen Lawang Bledheg, motif yang dipilih dari kedua alternatif desain tersebut adalah alternatif desain yang kedua. Hal ini didasari pada target audiens yang akan disasar adalah anak muda dengan rentan usia 15-30 tahun yang memiliki selera modern.

Penggunaan penggayaan dengan gaya abstract illustration, terlihat membentuk raut dengan bentuk blok geometris sehingga membentuk ilustrasi kepala naga secara abstrak. Menurut McCready (2019) dalam artikel 8 Biggest Graphic Design Trends For 2020 \& Beyond disebutkan bahwa Anak muda sekarang menyukai ilustrasi sederhana, keunikan, dan grafis sederhana dalam berbagai desain sekarang ini. Penggayaan seperti ini diikuti dengan penggunaan warna pop dengan menggunakan warna-warna terang dan kontras. McCready juga berpendapat bahwa ilustrasi yang menarik di 2020 adalah ilustrasi yang lebih imajinatif, abstrak, dan khayalan karena ilustrasi seperti itu memiliki kesan sederhana, unik, dan efektif.

Elemen-elemen yang diambil pada alternatif desain kedua dilakukan proses digitalisasi. Elemenelemen yang digitalisasi antara lain Kepala Naga, Tumpal, dan Surya Majapahit. Elemen tersebut didigitalkan menggunakan software desain vector.

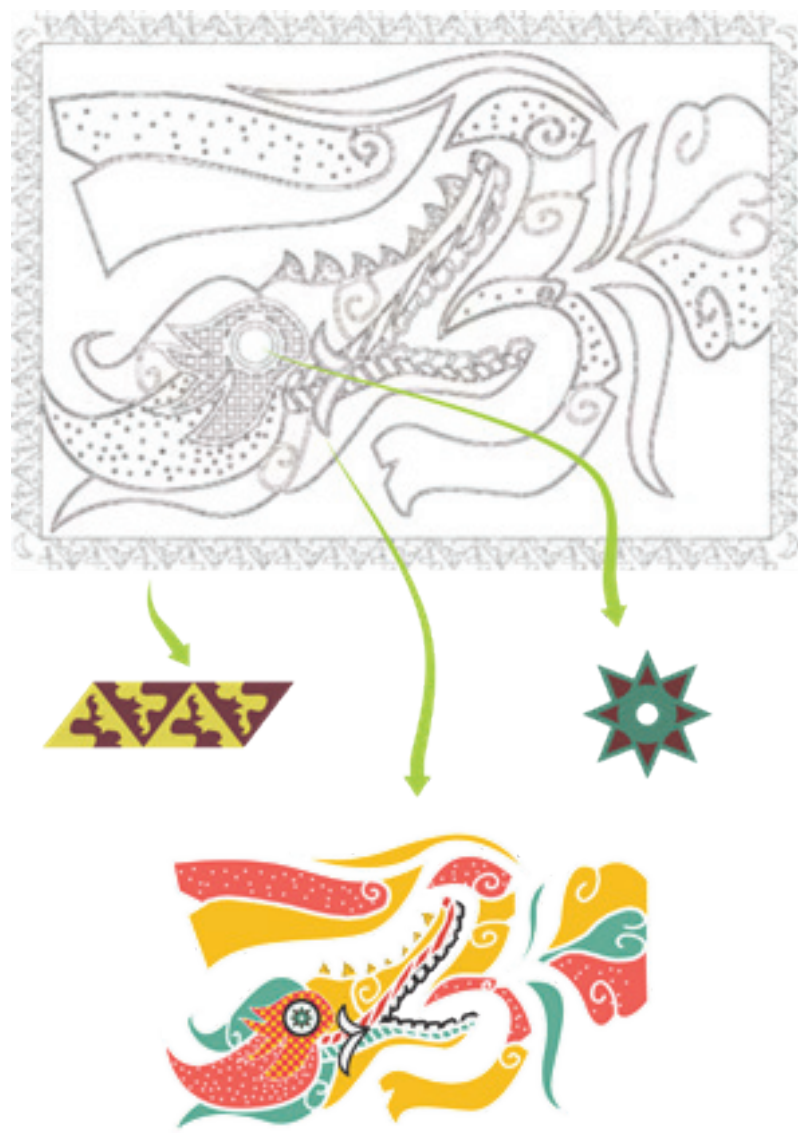

Gambar 8. Proses digitalisasi motif batik Lawang Bledheg (Sumber: Dokumentasi Abi Seno dkk., 2020)

Setelah dilakukan digitalisasi, proses selanjutnya adalah melakukan pewarnaan. Pewarnaan yang dilakukan menggunakan warna-warna muted color palettes. Muted color palettes merupakan warna yang menjadi tren pada tahun 2020 ini bagi anak muda (McCready, 2019). Muted color palettes adalah warna-warna yang sedikit diberikan desaturasi ke arah warna hitam dan putih, ataupun kearah warna komplementernya (Stone, 2006). Pada dasarnya, muted color palettes adalah warna komplementer dari warna vivid.

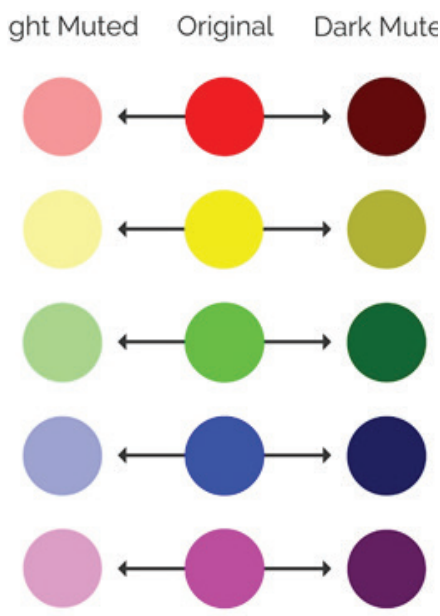

Gambar 9. Diagram warna muted color palettes (Sumber: McCready, 2019) 
Penerapan warna muted color palettes pada desain motif batik komtemporer khas Demak ini dilakukan dengan membuat dua alternatif warna. Alternatif warna pertama diarahkan pada warnawarna yang disaturasi ke arah putih dan alternatif warna kedua disaturasi ke arah warna hitam. Hal ini akan menjadikan kedua alternatif warna tersebut akan terlihat lebih muda dan lebih tua. Walaupun kedua alternatif warna terlihat kontras, tetapi pemilihan dan pengaturan warnanya tetap memperhatikan target audiens dari motif batik ini. Berikut adalah hasil dari alternatif warna desain motif batik komtemporer khas Demak tersebut.

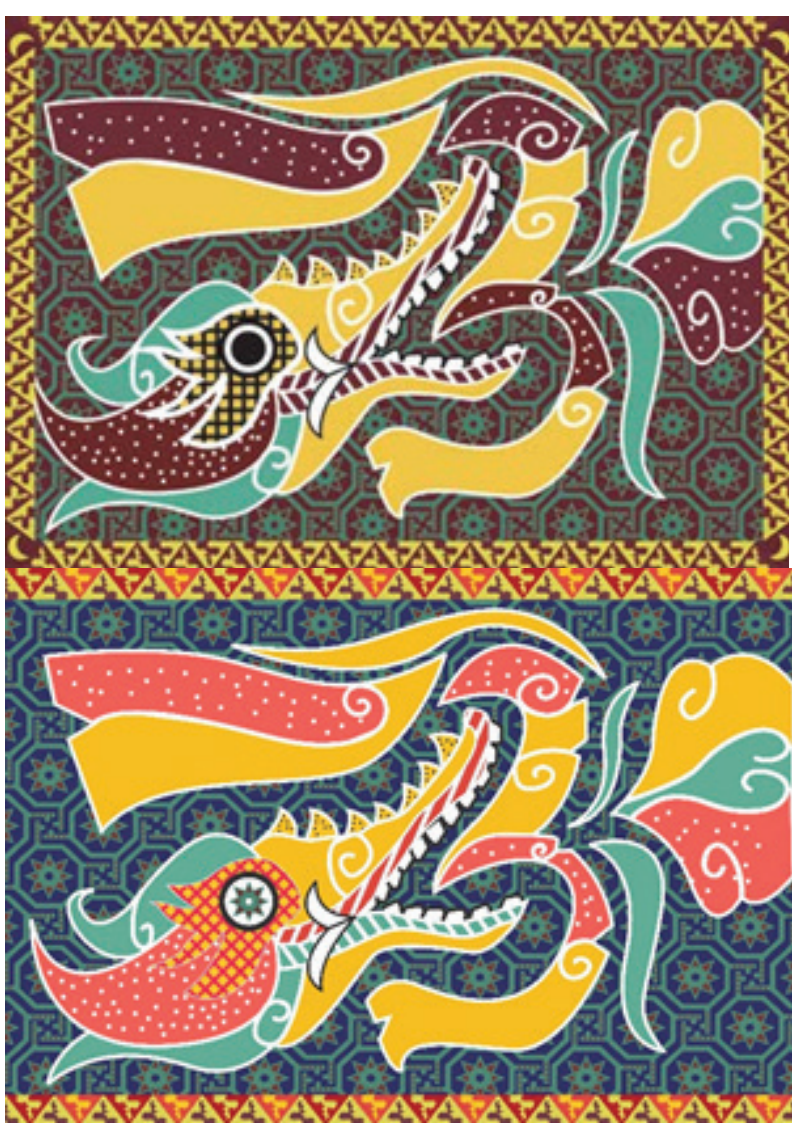

Gambar 10. Alternatif pewarnaan pada motif batik Lawang Bledheg kontemporer

(Sumber: Dokumentasi Abi Seno dkk., 2020)

Final desain untuk desain motif batik komtemporer khas Demak yang dipilih adalah desain dengan alternatif warna yang lebih ke arah warna-warna muda. Desain tersebut terlihat lebih dapat diterima oleh target audiens anak muda umur 15-30 tahun. Dengan desain motif batik komtemporer khas Demak yang seperti ini dapat membuat anak muda tertarik untuk menggunakannya.

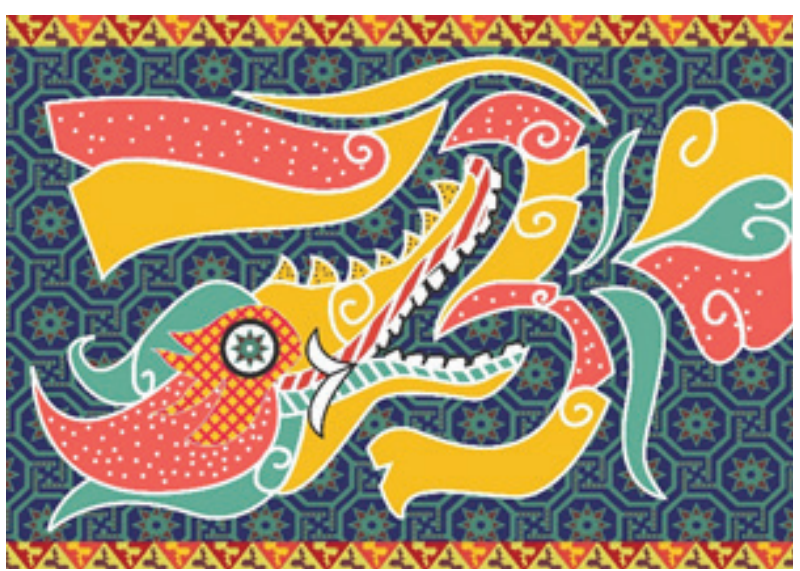

Gambar 11. Final desain motif Batik khas Demak berdasarkan pada Ornamen Lawang Bledheg (Sumber: Dokumentasi Abi Seno dkk., 2020)

Final desain motif batik kontemporer khas Demak dibuat gambaran perwujudannya (mockup) dalam sebuah kain. Hal ini dilakukan untuk mendapat gambaran apakah sudah sesuai dengan yang diharapkan. Dengan desain seperti ini, teknik penciptaan batik yang digunakan adalah teknik cap, teknik sablon, dan teknik cetak printing.

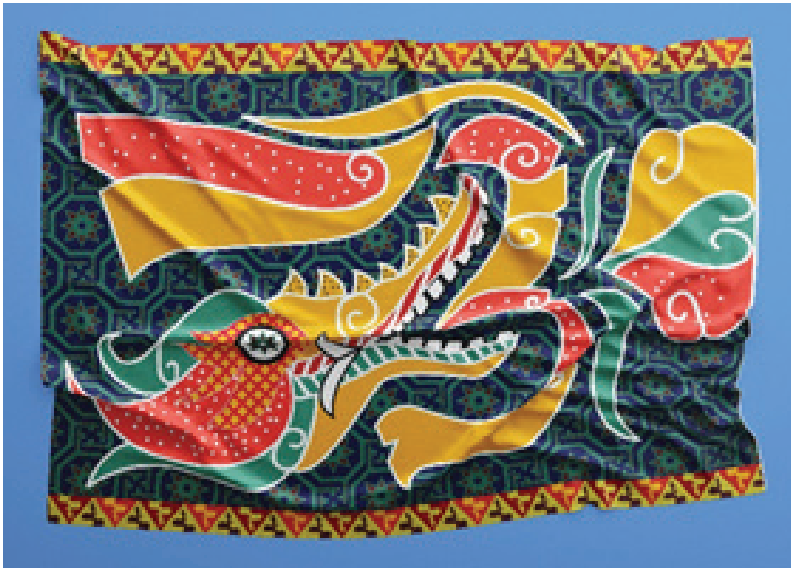

Gambar 12. Mockup tampilan motif Batik kontemporer khas Demak pada sebuah kain

(Sumber: Dokumentasi Abi Seno dkk., 2020)

Motif batik kontemporer khas Demak juga dibuatkan mockup pada penerapan dibeberapa media. Media yang coba ditampilkan untuk batik kontemporer khas Demak seperti tas totebag dan sarung bantal. Media-media penerapan kain batik pada anak muda sekarang sudah sangat berkembang. 


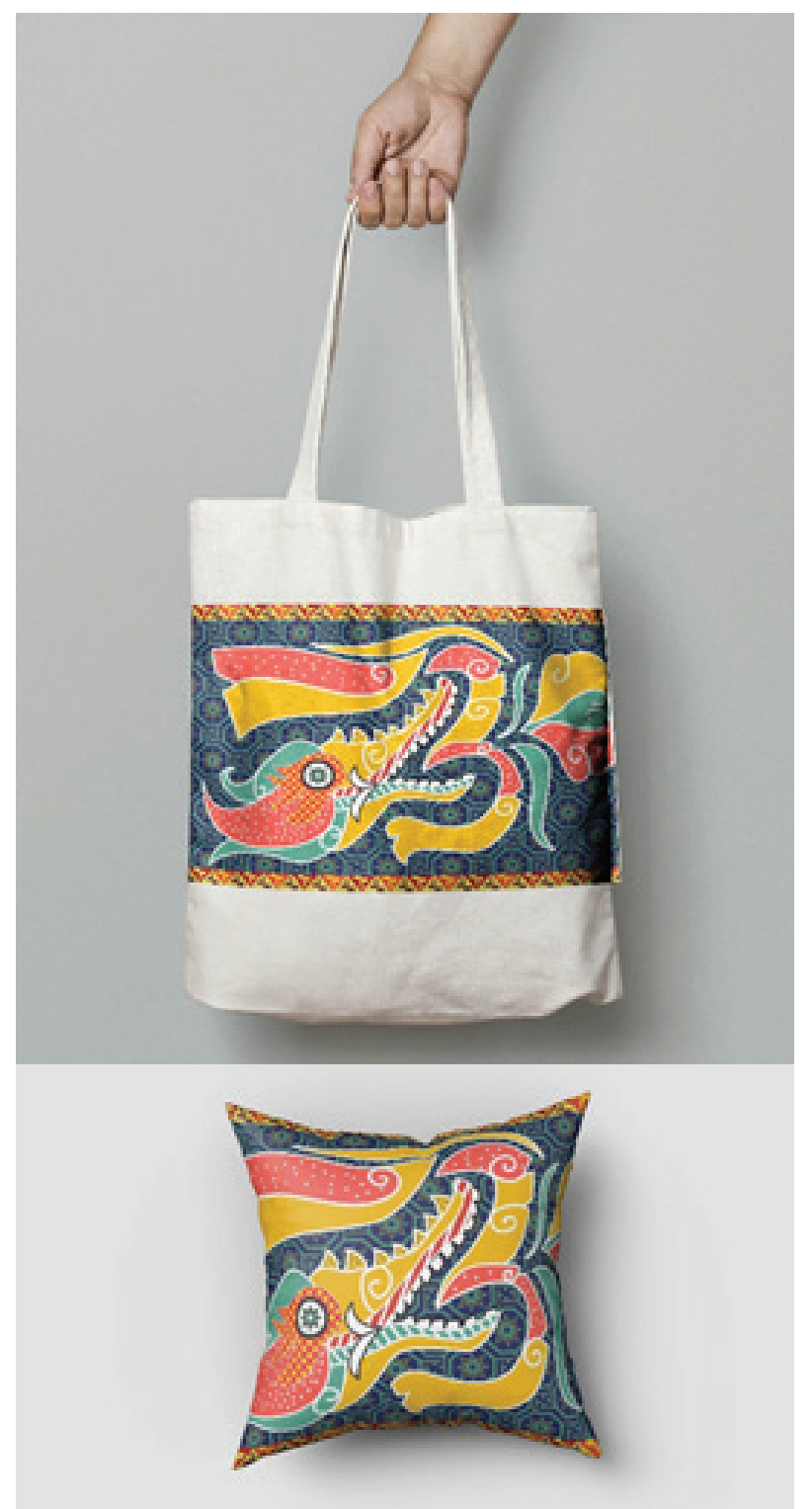

Gambar 13. Penetapan motif Batik kontemporer khas Demak pada tas totebag dan sarung bantal. (Sumber: Dokumentasi Abi Seno dkk., 2020)

\section{Simpulan}

Batik mengalami perkembangan fungsi, yakni tidak semata sebagai karya murni yang didesain untuk menampilkan nilai estetik, tetapi juga dapat digunakan dengan fungsi sebagai bahan untuk busana dan kelengkapan fungsional lainnya sebagai fungsi terapan. Penerapannya juga sudah berkembang dalam berbagai media seperti tas, topi, sarung bantal, mural, cat mobil, dan lain sebagainya. Hasil dari penelitian ini secara khusus melakukan penciptaan berkaitan dengan fenomena tersebut dalam mengekspresikan tematema ornamen interior pada masjid agung Demak ke dalam desain motif batik kontemporer.
Motif batik yang dihasilkan telah mempertimbangkan target audiens yang dituju yaitu anak muda usia 15-30 tahun. Motif batik tersebut telah mempertimbangkan tren yang berkembang dan sedang popular sekarang ini. Temuan motif batik kontemporer khas Demak tersebut merupakan wujud ekspresi dan identitas budaya khususnya tentang perbatikan Kabupaten Demak dalam memberikan penguatan identitas budaya lokal yang berbasis konservasi budaya melalui eksplorasi dan pengembangan desain motif batik kontemporer. Selain itu, motif batik yang digunakan dapat dijadikan sebagai motif rujukan pembatik di Kabupaten Demak.

\section{Ucapan Terimakasih}

Apresiasi setinggi-tingginya diberikan kepada Lembaga Penelitian dan Pengabdian Masyarakat Universitas Dian Nuswantoro Semarang yang telah memberikan dukungan penuh berupa dana penelitian penelitian dasar perguruan tinggi tahun 2019. Terimakasih juga kami sampaikan kepada Teddy Prakosa dan Noor Hasyim karena bantuannya pada penelitian ini.

\section{Daftar Pustaka}

Arisandi, B., Suciati, N., \& Wijaya, A. Y. (2011). Pengenalan Motif Batik Menggunakan Rotated Wavelet Filterdan Neural Network. JUTI: Jurnal Ilmiah Teknologi Informasi, 9(2), 15.

Ashari, M. (2013). Studi Bentuk, Fungsi Dan Makna Ornamen Makam Di Kompleks Makam RajaRaja Bugis. Dewa Ruci, 8(3), 444-460.

Gustami, S. P. (2007). Butir-butir mutiara estetika timur: ide dasar penciptaan seni kriya Indonesia. Yogyakarta: Prasista.

Gustami, S. P. (2008). Nukilan Seni Ornamen Indonesia. Yogyakarta: Arindo Nusa Media.

Karmila, M. (2010). Ragam Kain Tradisional Nusantara: Makna, Simbol, dan Funosi. Jakarta: Bee Media.

Kartika, D. S. (2005). Seni rupa moden. Bandung: Rekayasa Sains.

Marianto, M. D. (2006). Quantum Seni. Semarang: Dahara Prize.

Mayasari, M. S., Tulistyantoro, L., \& Rizqy, M. T. (2014). Kajian Semiotik Ornamen Interior Pada Lamin Dayak Kenyah (Studi Kasus Interior Lamin di Desa Budaya Pampang). Jurnal Intra, 2(2), 288-293. 
McCready, R. (2019). 8 Biggest Graphic Design Trends For 2020 \& Beyond. Retrieved February 17, 2020, from Venngage website: https://venngage.com/blog/graphic-designtrends/

Pebrianasari, V., Mulyanto, E., \& Dolphina, E. (2015). Analisis Pengenalan Motif Batik Pekalongan. Jurnal Techno.COM, 14(4), 281290.

Saragi, D. (2018). Pengembangan Tekstil Berbasis Motif dan Nilai Filosofis Ornamen Tradisional Sumatra Utara. Panggung, 28(2), 161-174.

Soedarso, S. P. (2006). Trilogi Seni : Penciptaan Eksistensi dan Kegunaan Seni. Yogyakarta: Badan Penerbit ISI Yogyakarta.

Stone, M. "Choosing colors for data visualization. . B. I. (2006). Choosing Colors for Data Visualization. Business Intelligence Network, 2.

Sudana, I. W. (2019). Fungsi Ornamen dalam Pengembangan Desain Fashion : Studi Kasus Ornamen Karawo di Gorontalo. Sandyakala: Prosiding Seminar Nasional Seni, Kriya, Dan Desain, 291-300.

Sunaryo, A. (2009). Ornamen Nusantara Kajian Khusus tentang Ornamen Indonesia. Semarang: Dahara Prize.

Supatmo. (2016). Keragaman Seni Hias Bangunan Bersejarah Masjid Agung Demak. Jurnal Imajinasi, 10(2), 107-120.

Supatmo. (2018). Ikonografi Ornamen Lawang Bledheg Masjid Agung Demak. Jurnal Imajinasi, 12(2), 29-40.

Wulan, P., \& Affandi, I. (2016). Memaknai Nilai Kesenian Kuda Renggong dalam Upaya Melestarikan Budaya Daerah di Kabupaten Sumedang. Journal of Urban Society's Art, 3(1), 27-35. 